\title{
Effects of Private and Government Owned Broadcast Media on Nigerian Public Opinion
}

\author{
${ }^{1}$ Asodike, Sylvia O. And $*^{2}$ Udoh, Victoria C. \\ ${ }^{I}$ Department Of Mass Communication, Tansian University, Umunya, Anambra State, Nigeria. \\ ${ }^{1}$ General Studies Unit, Tansian University, Umunya, Anambra State, Nigeria.
}

Abstract: Effects of private and government broadcast media on public opinions in Nigeria were evaluated. The researcher looked at effects of these two broadcast media on the listening/viewing audience in Onitsha Anambra State, Nigeria. This was done through probing of the effects of broadcasting using the news and programmes of private broadcast media, accounts of events, expressing of divergent views, credibility and acceptance of the media and message broadcast by both media were also tested. One hundred questionnaires were used to collect data for thisresearch. The whole questionnaires were returned. The results of findings among other things showed that private broadcast media positively influenced public opinion and as well encouraged the expression of divergent views.

Keywords: Public opinion, government media, private media and Nigeria.

\section{Introduction}

Both private and public electronic media affect the public by helping them to form opinion and at the same time help them to change it. They do this by helping to give the media consumers what to think about. [1] saidthat those pictures created by human beings in their heads, the purpose and relationships are their public opinions. Radio and television help to create these pictures through their messages and news.

Public opinion is not only affected by the pictures in our heads. [2] believes that economic position and property acquired account for differences in opinion held over an issue. Opinion formation is also dependent on the use the individual want to put to the message. The use which one will put information to is conversely determined by his "ego" involvement, perceptions, judgment, social and educational background a, among other things. How broadcast stations influences public opinion depends on whether the audience have confidence in it. The confidence in any station is a function of how credible its message are; how it is dedicated to truth and facts [2, 3,4 and 5].

Any station which presents distorted information will tend to lose credibility. The result is that the viewing and listening audience will look elsewhere. Perhaps they may add up from informal sources thereby adding to the distortion [6].

Mass media wield an enormous power in shaping and reshaping of events $[7,8,9$ and 10]. They persuade, crusade, set agenda, act as watchdog of the society, educate, inform, mobilize people to agitate for their rights or reject government actions or policies, they entertain and also act as status conferrer.

The newspaper is very aggressive in performing the watchdog and setting functions of the mass media but research has shown that despite the enormous power wielded by print media the electronic media has overtaken them thrusting and passing to all fabrics of the society: culture, politics, education, music and sports due to immediacy of their news thereby touching the lives of the young, adult, the aged, the poor, the rich, educated and illiterate cutting across all ethnic and religious groups affecting their norms, belief systems, dressing patterns, attitude and social behavior [11,12,13,14, 15 and 16]. This makes it easy for electronic media to mould and sustain opinion and at the same time easily sway such opinion.

Electronic media capabilities may be attributed to the immediacy their news, their "global village effect" high penetrability of the media to the audience in the cities and remote villages, disseminating the same message at the same time to heterogeneous mass of people.

Radio on the other hand is the widest and most popularly used mass medium in Nigeria. Nearly every household in Nigeria especially in Anambra state has a radio set [17, 18 and 19]. That is why researchers say that radio has the highest penetrability to the Nigerian audience, talking to them in the farm, in the house, on the road while, traveling or on evening stroll using the 'walkman' in the office while working and while reading. No wonder coup plotters easily battle to capture Federal Radio Corporation of Nigeria (FRCN) to announce their coup[20 and 21].

Governments (especially in Africa ) use the broadcast media to disseminate information to the citizenry, soliciting support from the populace for their programmes and mobilizing people to perform certain duties expected of them and to support from the populace for their programmes and mobilizing people to perform certain duties expected of them and support their policies [22, 23, 24, 25 and 26]. 


\section{STATEMENT OF RESEARCH PROBLEM}

However, even in the democracy setting like in Nigeria of today, the public broadcast stations in their news and programmes do not tell the people the whole truth about events happening around them. They are biased in favour of the government of the day, helping the government to propagate lies, truncate the truth, vilify the oppositions, falsify issues, engage in mudslinging of opponents and acting as government's megaphone just like it is said that "he who pays the piper dictates the tune. By doing this, public opinion is seriously wounded as the public are confused on issues. The motives behind the news are understood by some while others are fooled, believing everything the government puts forth.

Because of this problem, the credibility and acceptance of public media news are questioned, issues are distorted. Inspite of this, public broadcasts still affect public opinion.

It is now the interest of the researcher to see how far privately owned media will go on in solving the problem of credibility and acceptance and how they will help to shape and reshape public opinions in Nigeria.

\section{OBJECTIVE OF THE STUDY}

The main objective of this study was to find out what effect private and government owned media have on public opinion in Nigeria. This will help us understand how broadcasting has changed now that competition has entered into the broadcast industry.

The study will also find out whether the motive behind the news and programmes affect the credibility of the media and how all these affect the perceptions of the public as well as how they will help to form and sustain public opinion.

How best the broadcast media will be used to achieve the best result in inculcating and creating political awareness, telling the public truth and instituting positive norms and values in our system.

\section{Research Methodology}

This study was carried out on the broadcast audience within Onitsha, Anambra State, Nigeria. Survey research method was used to enable the respondents focus their minds towards the goal of this research. The data collected from 100 respondents were statistically evaluated.

\section{SAMPLE SIZE}

One hundred (100) respondents were selected from civil and public servants between the ages of 26-35 years. Onitsha was chosen because the private and government owned electronic media were many in the metropolis.

\section{TARGET POPULATION}

The targeted population was made up of both civil and public servants between the age 26-35 years and income levels of N6, 500 and N26,000 monthly.

\section{SAMPLE TECHNIQUE}

The researcher grouped Onitsha - the universe into five (5) phases. Phases I and II started from Amanator down to Nwaziki. Phases III and IV covered all the streets from Awada to Fegge. Phase 5 covered Island Town. Each phase got 20 respondents and hence 20 questionnaires were allocated to them.

Simple random sampling was used to select the streets from each phase. The names of the streets were written on separate piece of paper and folded. These were put in a basket and thoroughly mixed before the selection. Selection was without replacement.

This gave other streets equal chances of being selected. After selecting the streets, the questionnaires were distributed to the respondents using random sampling.

\section{INSTRUMENT FOR DATA COLLECTION}

One hundred questionnaires were used for the study. They were distributed to the selected respondents in the selected streets using random sampling.

Questions focusing on the topic of the study were asked. The questions would include demographics such as age, sex, income, occupation etc.

The questionnaires were self administered by the researcher so as to reach the respondent on time to avoid unnecessary delay if mailed.

\section{DATA COLLECTION}

Questionnaires were administered to the 100 sample randomly selected for the study. Close- ended questions were mostly used. This ensures that the respondents focused their attention on the objectives of the 
study. It also allows for easier coding of the data collected. Small percentage of open -ended questions was used to ensure that in-depth information was realized.

\section{DATA ANALYSIS AND HYPOTHESIS TESTING}

The data for this study were collected through survey research technique and analyzed using descriptive and inferential statistics. Data collected were presented and analyzed using tables, simple bar charts and pie charts. Research questions and three hypotheses were tested using chi-square statistical technique.

In order to test the hypotheses formulated in this study, data presented and analyzed were generated from primary sources using 100 copies of the questionnaires distributed to the 100 respondents by simple random sampling method of selection. The whole questionnaires were dully filled and returned as expected since they were self administered by the researcher.

\section{Data Presentation}

The preliminary analyses of this study based on demographic factors: sex, age, occupation, educational level and income level per month. Other data analyzed were based on the research questions and the hypotheses.

TABLE: 1SEX OF THE RESPONDENTS

\begin{tabular}{|l|l|l|}
\hline Sex & Frequency of response & $\%$ of Response \\
\hline Male & 46 & 46 \\
\hline Female & 54 & 54 \\
\hline Total & 100 & 100 \\
\hline
\end{tabular}

From the table presentation of the 100 respondents, 46 were males constituting $46 \%$ of the response while 54 female constituting $54 \%$ of response.

Table :2AGE OF THE RESPONDENTS

\begin{tabular}{|l|l|l|l|}
\hline Age & Response & Frequency of response & \% of Response \\
\hline $26-30$ & & 52 & 52 \\
\hline $31-35$ & & 48 & 48 \\
\hline & Total & 100 & 100 \\
\hline
\end{tabular}

The age distribution from table 2 showed that the response was slightly higher in age group of [26-30] that recorded (52\%)for52 respondentsagainst the age bracket of [31-35] that recorded (48\%) for 48 respondents.

TABLE: 3OCCUPATIONS OF THE RESPONDENTS

\begin{tabular}{|l|l|l|l|}
\hline Occupation & Response & Frequency & $\%$ of Response \\
\hline & Civil servant & 67 & 67 \\
\hline & Public servant & 33 & 33 \\
\hline & Total & 100 & 100 \\
\hline
\end{tabular}

In the occupation category, the frequency of response was $67: 33$ for the civil and public servants as shown in table 3 above. This constituted $67 \%$ of the civil servants and $33 \%$ of the public servants.

TABLE: 4 EXISTENCE OF PRIVATE BROADCASTING

\begin{tabular}{|l|l|l|l|}
\hline Question 1 & Response & $\begin{array}{l}\text { Frequency of } \\
\text { Response }\end{array}$ & \% of Response \\
\hline $\begin{array}{l}\text { Do you know that private } \\
\text { broadcasting has started } \\
\text { operating in Nigeria. }\end{array}$ & $\begin{array}{l}\text { Nos } \\
\text { Total }\end{array}$ & 98 & 98 \\
\end{tabular}

Question on the existence of private broadcasting in Nigeria showed that 98\% (98 respondents) answered 'yes' while only $2 \%$ (2 respondents) said 'NO' that they were not aware. Since more than two-thirds majority of the respondents were aware of the existence of private broadcasting in Nigeria, the researcher expected the respondents to be well informed as well as being in the position to look at both private and public media critically. 
TABLE 5: DURATION OF AWARENESS OF PRIVATE BROADCASTING

\begin{tabular}{|l|l|l|l|}
\hline Question 2 & Response & $\begin{array}{l}\text { Frequency of } \\
\text { Response }\end{array}$ & \% of Response \\
\hline \multirow{3}{*}{ How long have you been aware? } & One year & 8 & 8 \\
& $\begin{array}{l}\text { 3 years } \\
\text { 7 years } \\
\text { and above } \\
\text { Total }\end{array}$ & 28 & 28 \\
& 64 & 100 & 100 \\
\hline
\end{tabular}

The respondents were asked to indicate how long they have been aware of private broadcasting operation in Nigeria. The table showed that only $8(8 \%)$ respondents said one year while $28(27 \%)$ answered 3 years and 64 (64\%) have been aware for 7 years and above. The responses have showed that at least $64 \%$ of the respondents were in better positions to know how the message from private broadcasting look like.

TABLE 6: NEWS AND CURRENT AFFAIRS OF PRIVATE BROADCAST MEDIA.

\begin{tabular}{|l|l|l|l|}
\hline Question 3 & Response & $\begin{array}{l}\text { Frequency of } \\
\text { Response }\end{array}$ & \% of Response \\
\hline $\begin{array}{l}\text { Do you listen to } \\
\text { privateBroadcast stations news } \\
\text { and current affairs programme } \\
\text { of public interest? }\end{array}$ & Yes & 98 & 98 \\
\hline
\end{tabular}

In response to question 8,98\% (98) respondent said 'Yes' that they listen to news and current affairs programmes of private broadcast stations; 2 said 'No' this showed that the respondents were better positioned to answer how public opinion were affected by private broadcast media.

TABLE 7: EXPRESSING OF DIVERGENT VIEWS.

\begin{tabular}{|l|l|l|l|}
\hline Question4 & Response & $\begin{array}{l}\text { Frequency of } \\
\text { Response }\end{array}$ & \% of Response \\
\hline $\begin{array}{l}\text { Do you think that private } \\
\text { Broadcast media encourage } \\
\text { expressing of divergent views. }\end{array}$ & Yes & 89 & 89 \\
& No & 11 & 11 \\
& & & \\
& Total & 100 & 100 \\
\hline
\end{tabular}

Eighty-nine $(89 \%)$ of the respondents said 'yes while only $11 \%$ 'No' since the greater majority of the respondents favored private broadcast media, one may then conclude that private broadcasting media encouraged expressing of divergent views

TABLE: 8 INFLUENCE OF PRIVATE MEDIA ON PUBLIC OPINION.

\begin{tabular}{|l|l|l|l|}
\hline Question 5 & Response & $\begin{array}{l}\text { Frequency of } \\
\text { Response }\end{array}$ & of Response \\
\hline To what extent do & & 86 & 86 \\
Private broadcast media & Greatly & 10 & 10 \\
influence public opinion? & Little or less & 4 & 4 \\
& Less significant & 100 & 100 \\
\hline
\end{tabular}

Eighty-six percent $(86 \%)$ of the respondents answered that private broadcast media greatly influenced public opinion. $10 \%$ said that the influence was little or small while $4 \%$ said that it was less significant.

TABLE 9: POSITIVE INFLUENCE OF PUBLIC OPINION

\begin{tabular}{|l|l|l|l|}
\hline Question 6 & Response & $\begin{array}{l}\text { Frequency of } \\
\text { Response }\end{array}$ & \% of Response \\
\hline $\begin{array}{l}\text { Can you say that private } \\
\begin{array}{l}\text { Broadcast media exert more positive } \\
\text { influence on public opinion than } \\
\text { government owned media.* }\end{array}\end{array}$ & Yes & 83 & 83 \\
& Total & 17 & 17 \\
\hline
\end{tabular}

A great majority of the respondents (83\%) answered 'yes' that private broadcast media exert more positive influence on public opinion than government owned media ; $17 \%$ disagreed. What this signified was that majority of the viewers do not tend to be moved positively or benefit from government owned broadcast media. The result further shows that private broadcast is people oriented. 
TABLE 10: INDEPTH COVERAGE OF EVENTS.

\begin{tabular}{|l|l|l|l|}
\hline Question 7 & Response & $\begin{array}{l}\text { Frequency of } \\
\text { Response }\end{array}$ & \% of Response \\
\hline $\begin{array}{l}\text { Which present more } \\
\text { indepth coverage of } \\
\text { events? }\end{array}$ & $\begin{array}{l}\text { Government Broadcast } \\
\text { Media. }\end{array}$ & 24 & 24 \\
& $\begin{array}{l}\text { Private Broadcast media } \\
\text { Both }\end{array}$ & 72 & 72 \\
& \multicolumn{1}{|c|}{ Total } & 100 & 4 \\
\hline
\end{tabular}

Twenty four (24\%) of the respondents said that government media present more indepth coverage of events; $72 \%$ representing 72 respondents favoured private broadcast media while $4 \%$ representing 4 respondents said that both do present indepth coverage of events.

\section{Results}

From the results of table $6,7,8$ and 9 , private broadcast media influences public opinion more than that of government owned media. This might be because of the way private broadcast media present their news and current affairs. It could also be as suggested from the responses that they want to be socially responsible to the public. Response to question shows that the influence exerted on public opinion by private broadcast media is greater. Others believe that private broadcast media help to shape and reshape public opinion. The results also showed that private broadcast media evoke more credibility and acceptance than government owned broadcast media. Reasons were that private broadcast media are out for profit making and because of that in order to attract the public, they project the truth and report events factually and objectively. They also give more comprehensive and interpretative analysis of events. By so doing, they tend to reverse unwholesome image created by the government broadcast media which serves as government megaphone. The implication is that both advertisers and policy makers patronize them since they have greater audience and outreach $[27,28$ and 29].

Analysis of the response to the question for this study shows that private broadcast media encourage the expressing of divergent views more than government owned broadcast media. The reason is that private broadcasting has more respect for individual opinion and as such will not suppress such opinion to favour anybody like those of the government owned broadcast media. Again, private broadcast media create awareness through which more and more feed back to issues is analyzed and thus help to project public stand on any issue of public interest irrespective of one's political inclination. This shows that private broadcasting live to the expectations of what every media outfit would be "a market place of ideas" they operate under the auspices of social responsibility theory; which allow divergent views and are socially responsible.

It is also clear from the results of this study that the motive behind the news and programmes of public interest of private broadcast media messages attract public confidence more than those of government owned broadcast stations. The reason for this is that private broadcast media give more account of events. They exert greater influence on public opinion than government broadcast media since they allow expression of divergent views on an issue. Private broadcast media are not as biased as their government counterparts. Another reason is that the role played by government broadcasting when it comes to any controversial issue of public interest is not encouraging. They distort the fact to favor the government.

In other case, as many be seen from the agenda setting hypothesis of the media, government broadcasting outfits, may project the issue so that the public will see it as not being important. What happens here is that people will not give serious thought to such an issue and take it as not necessary. With private broadcasting, the true pictures of events emerge, hence the confidence from the audience.

\section{Conclusion}

In conclusion, the outcome of this research showed that the opinions of the people in OnitshaAnambra State, Nigeria were greatly influenced by private broadcast media. The research also showed that private broadcast media evoke more credibility and acceptance than the government owned broadcast media. It was confirmed too that motive behind the news affects the acceptance of such messages broadcast and this motive is the controlling variable between the two broadcast media. More importantly, it was found out that private broadcast media messages affect the public positively and that their influence on public opinion is positive since they give more indepth coverage of events than public broadcasting outfits. In a democratic setting, the publics are allowed to express their opinions. This is the make of democracy. In this research, it was confirmed that private broadcast media do not suppress opinion rather they encourage the expressing of divergent views.

Furthermore, private broadcast media give accurate accounts of events and as a result, this research confirmed that they attract very high confidence level from the listening/viewing audience. This high level of confidence exists because they report events factually and objectively without message distortion. 
Finally, it can be seen from the result of the research that private broadcast media help to shape and reshape public opinion and as such they can be used positively for national building.

\section{Recommendation}

Based on the findings and limitation of this study, it is now necessary to make some recommendations and suggestions that might be valuable to the government and its agencies whose concern is to get positive public opinion on issues concerning government policies. Since private broadcast media greatly influence public opinion, government should encourage them and use them positively for national building. Government of the day should also see private broadcasting outfit as partners in progress and as such make policies that will allow them to survive and grow. It is also recommended that private broadcast media should not be intimidated by the government negative activities. They should not be threatened with the withdrawal of their licenses. More private broadcast media should be encouraged to spring up to make up for the lapse in the existing ones. This can be done by issuing more licenses to people to start operating.

From the research government broadcast media should do something to increase their credibility and acceptance by the public.

This can be done by reporting events factually and objectively and stop negative broadcasting. This will help the public to develop confidence on them.

As a matter of necessity, government broadcast media need to encourage the public to come and express their differing views with government in the media in order to create climate of fairness and just governance.

Furthermore, research in this areas should try to find out how private broadcast media can increase their financial base. Research could be carried out on how to improve the levels of message sourcing, storage and retrieval. Finally, the same or similar research should be carried out in other parts of the country.

\section{References}

[1]. Defleur,Melvin L. and Dennis Everette E. (1972) UNDERSTANDING MASS COMMUNICATION. Boston Houghton Miffin company Boston.p 290-293

[2]. Champion Newspaper (Sept. 13, 2001) It is an act of war"' Frontpage.

[3]. Thomas S.N.P and Lee Philip (1996). MEDIA FOR DEVELOPMENT.LondonBathly Brothers Ltd. P7-8.

[4]. Emery and Smythe (1986) READINGS IN MASS COMMUNICATION, CONCEPTS AND ISSUES IN MASS MEDIA. W.M.C Browns publishers $6^{\text {th }}$ edition. P439.

[5]. Thomas and Lee (1996) MEDIA FOR DEVELOPMENT, London Bathly Brothers Ltd.P8.

[6]. Little - John (1996) THEORIES OF HUMAN COMMUNICATION. Wadsworth publishing company p385.

[7]. Lippman, Walter (1922). PUBLIC OPINION, New tort Macmillian p 1-20.

[8]. Emery and Smythe (1986). READING IN MASS COMMUNICATION, CONCEPTS AND ISSUES IN MASS MEDIA. Brown publishers $6^{\text {th }}$ edition p. 170 .

[9]. Voelker, Voelker (1972) MASS MEDIA FORCESIN OUR SOCIETY. New York, Harcourt Brace P240.

[10]. Arnold, Edward (1994). COMMUNICATION STUDIES AN INTRODUCTORY READER P196-156.

[11]. Glynn, Carroll J. (1987) JOURNALISM QUARTERY WINTER Vol. 688

[12]. Sullivan, Tim O. et al., (1994) STUDING THE MEDIA AN INTRODUCTION, London. Hodder Headline Group 338 Euston Road P 155-156.

[13]. Emery and Smythe (1986) READING IN MASS COMMUNICATION CONCEPTS AND ISSUES IN MASS MEDIA. Brown Publishers $6^{\text {th }}$ edition $\mathrm{p} 553$

[14]. Sears David O. et al (1988) SOCIAL PSYCHOLOGY $6^{\text {th }}$ edition P 553.

[15]. Owen Diane (1999); paper on “ EFFECTS OF ELECTRONIC MEDIA ON DEMOCRATIC ATTITUDES “ Stuttgart Germany Georgetown University, state Agency for civic education p3-10.

[16]. Smith, Headrick (1988) THE POWER GAME, HOW WASHINGTON WORKS, Canada Rodon House of Canada LTD. P37.

[17]. Lippman Walter (1922). PUBLIC OPINION, New York Macmillian P223-224.

[18]. MacBride (1980) MANY VOICES ONE WORLD Ibadan, Paris University press, Ibadan and UNESCO press, p158

[19]. MCLeish Robert (1994) RADIO PRODUCTION $3^{\text {rd }}$ edition Bath press P2.

[20]. Starobin (May 25, 1996) NATIONAL JOURNAL “ON THE SQUARE”' P 145-9.

[21]. Cappella and Jamieson (1997) SPIRIT OF CYNICISM, New York Oxford University press P5.

[22]. Mcleish, Robert (1994) RADIO PRODUCTION $3^{\text {rd }}$ Bath press P 81.

[23]. Ibrahim, Audusonet al., (1998) Daily Times Wednesday July 15 "DRESSING RUMOURS AS NEWS TO THE PUBLIC" " ROLE OF MEDIA IN THE SOCIETY " p15-16.

[24]. Shawolu, Rima (1998) Daily Times Wednesday July 15 P16.

[25]. Ita Bong (1998) Vanguard Wednesday July 8 P11.

[26]. Tan,S. Alexis et al (1987). Journalism Quarterly sping vol. 64 no 1 " AMERICAN TV IN THE PHILIPINES : A TEST OF CULTURAL IMPACT'’. P65.

[27]. Emery and Smythe (1986) READING IN MASS COMMUNICATION, CONCEPTS AND ISSUES IN MASS MEDIA W.M.C. Brown Publishers.

[28]. Thomas N.P and Lee Phili (1996). MEDIA FOR DEVELOPMENT . London Bathly brothers Ltd.

[29]. Wimmer and Domnick (1996). MASS MEDIA RESEARCH, AND INTRODUCTION copyright, wardswosrt publishing company. 